\title{
RYVÄSSIPULIN (ALLIUM CEPA L. v. SOLANINUM ALEF.) IDÄ- TYKSEN VAIKUTUKSESTA KUKINTOJEN KEHITTYMISEEN JA SIPULIN VERSOMISEEN VARASTOSSA.
}

\author{
KLAus Aura
}

Kasvitautien tutkimuslaitos, Tikkurila.

Koleat säät kasvukauden alussa aiheuttavat usein kukintovanojen kehittymistä ryvässipuliin silloinkin, kun istukkaat on edeltäneenä varastokautena säilytetty lämpimässä $\left(18-24^{\circ} \mathrm{C}\right.$ ) varastossa (vrt. 2). Kasvukauden 1957 alku oli hyvin kylmä, mistä syystä sipulin runsas kukkiminen oli yleinen satoa alentava tekijä miltei koko maassa. Istuttamalla sipuli verraten myöhään voidaan kevätkylmistä aiheutuvaa kukkimista välttää (vrt. 3). Myöhäisestä istutuksesta aiheutuu kuitenkin huomattavia haittoja. Myöhään istutetun sipulin tuleentuminen viivästyy, mistä saattaa olla seurauksena ennenaikainen versominen varastossa, kuten BosWELL (1) on osoittanut. Myöhäistä korjuuta haittaavat lisäksi syksyn runsaat sateet, jotka myös hidastavat sipulin tuleentumista ja kuivumista. Tällöin voivat sipulit saada jo kasvupaikallaan voimakkaan harmaahomesaastunnan, joka etenkin lämpimässä varastossa leviää ja aiheuttaa säilytystappioita (2).

Kasvitautien tutkimuslaitoksen kokeissa vuosina $1956-57$ on sipulin tuleentumista pyritty jouduttamaan idättämällä istukkaita keväällä välittömästi ennen istutusta. Vuonna 1957 suoritetussa kokeessa oli lisäksi tarkoituksena selvittää, voidaanko kevätkylmistä aiheutuvaa kukkimista estää idättämällä sipuleita sopivassa lämpötilassa.

Kokeeseen v. 1957 käytetyt sipulit (Hytti) oli säilytetty $20-24^{\circ} \mathrm{C}$ lämpötilassa. Istukkaiden läpimitta oli keskimäärin n. $4 \mathrm{~cm}$. Idätys tapahtui lämmittämättömässä kasvihuoneessa istuttamalla sipulit kosteaan turvepehkuun 4:n, 8:n ja 13 päivän ajaksi. Jokaisessa koejäsenessä oli $4 \times 42$ istukasta. Maksimilämpötila kasvihuoneessa vaihteli päivittäin idätyksen aikana $+25.5-+32.5^{\circ} \mathrm{C}$ ja oli keskimäärin $30.0^{\circ} \mathrm{C}$. Minimilämpötila vaihteli vastaavasti $+5.5-+13.5^{\circ} \mathrm{C}$ ja oli keskimäärin $8.9^{\circ} \mathrm{C}$. Idätysajan keskilämpötila oli n. $19^{\circ} \mathrm{C}$. Versominen kasvihuoneessa oli epätasaista. Ennen istutusta avomaalle oli 13 pv idätetystä sipulista selvästi versonut $53 \%$ (versojen pituudet vaihtelivat $1-10.5 \mathrm{~cm}$ ), 8 pv idätetystä $19 \%$ (versojen pituudet $1-4.5 \mathrm{~cm}$ ) ja $4 \mathrm{pv}$ idätetystä $2.4 \%$ (versojen pituudet $1-2 \mathrm{~cm})$. Kaikkiin sipuleihin oli kehittynyt juuret. 
Sipulin istutuksen $(24,5 .-57)$ jälkeen vallitsivat kylmät säät. Ensimmäisen viikon aikana oli vuorokauden minimilämpötila maan pinnassa keskimäärin $0.6^{\circ} \mathrm{C}$ (vaihtelu $-2.3-+1.8^{\circ} \mathrm{C}$ ) ja maksimilämpötila $11.8^{\circ} \mathrm{C}$ (vaihtelu $+7.1-+18.2^{\circ} \mathrm{C}$ ). Viikon keskilämpötila oli $7.2^{\circ} \mathrm{C}$. Seuraavakin viikko oli vielä kylmä (keskilämpötila $10.3^{\circ} \mathrm{C}$ ); vasta sen jälkeen ilmat lämpenivät. Kasvukauden aikana todettiin, että idättämättömään sipuliin kehittyi erittäin runsaasti kukintovanoja, lähes $5000 \mathrm{kpl}$ aaria kohti. Neljän päivän idätysaika alensi kukintovanojen luvun 340 kappaleeseen aarilla. Kahdeksan ja kolmentoista päivän idätykset estivät kokonaan kukintovanojen syntymisen (taulukko 1, kuva 1). Siten on pääteltävissä, että istutuksen jälkeinen verraten lyhytkin lämmin kausi riittää estämään sipulin kukintaa, vaikka ilmat myöhemmin muuttuisivat kylmiksi.

Taulukko 1. Ryvässipulin idätyskoe Tikkurilassa v. 1957. Koeruudut $3.14 \mathrm{~m}^{2}$. Kerranteita 4 kpl. Riviväli $30 \mathrm{~cm}$, istutusetäisyys $25 \mathrm{~cm}$. Istutus 24. 5, nosto 6. 9. Sipulikanta: Hytti.

Table 1. Multiplier onion germination experiment at Tikkurila, 1957. Experimental aquare $3.14 m^{2} .4$ Replicates. Distance between rows $30 \mathrm{~cm}$, distance between sets $25 \mathrm{~cm}$. Setting on 24.5 , lifting on 6.9 . Variety of onion: Hytti.

\begin{tabular}{|c|c|c|c|c|c|c|c|c|}
\hline \multirow{3}{*}{$\begin{array}{l}\text { Koejäsen } \\
\text { Test group }\end{array}$} & \multirow{3}{*}{$\begin{array}{l}\text { Kukinto- } \\
\text { vanoja } \\
\text { kpl/a } \\
\text { Flower } \\
\text { stalks } \\
\text { no./are }\end{array}$} & \multirow{3}{*}{$\begin{array}{c}\text { Kukinto- } \\
\text { vanallisia } \\
\text { kasveja } \\
\text { Plants } \\
\text { with flo- } \\
\text { wer stalks } \\
\%\end{array}$} & \multirow{3}{*}{$\begin{array}{c}\text { Kukkineissa } \\
\text { kasveissa ku- } \\
\text { kintovanal- } \\
\text { lisia tytär- } \\
\text { sipuleita } \\
\text { Bulbs with flo- } \\
\text { wer stalks in } \\
\text { plants alveady } \\
\text { flowered } \\
\% \\
\end{array}$} & \multicolumn{2}{|c|}{$\begin{array}{l}\text { Sato } \\
\text { Yield }\end{array}$} & \multirow{3}{*}{$\begin{array}{l}\text { Jakau- } \\
\text { tuminen } \\
\text { kpl/yksilö } \\
\text { Divisions } \\
\text { no./indi- } \\
\text { vid. }\end{array}$} & \multirow{2}{*}{\multicolumn{2}{|c|}{$\begin{array}{c}\text { Kukintovanallisia } \\
\text { sipuleita sadosta } \\
\text { No. of onions with } \\
\text { flower stalks in to- } \\
\text { tal yield }\end{array}$}} \\
\hline & & & & \multirow{2}{*}{$\begin{array}{l}\mathrm{kg} / \mathrm{a} \\
\text { kg/are }\end{array}$} & \multirow{2}{*}{ 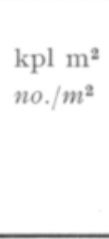 } & & & \\
\hline & & & & & & & $\begin{array}{l}\text { paino- } \% \\
\% \text { weight }\end{array}$ & $\begin{array}{l}\mathrm{kpl- \%} \\
\% \text { no. }\end{array}$ \\
\hline \multicolumn{9}{|l|}{ Idättämätön } \\
\hline $\begin{array}{l}\text { Ungerminated } \\
4 \text { pv idätetty }\end{array}$ & 4950 & 95.8 & 85.0 & 112 & 47.4 & 3.5 & 49.5 & 80.7 \\
\hline $\begin{array}{l}4 \text { days germination } \\
8 \text { pv idätetty }\end{array}$ & 340 & 7.7 & 66.0 & 322 & 58.3 & 4.4 & 1.1 & 4.9 \\
\hline $\begin{array}{l}8 \text { days germination } \\
13 \text { pv idätetty }\end{array}$ & 0 & 0.0 & - & 334 & 57.2 & 4.3 & 0.0 & 0.0 \\
\hline 13 days' germination & 0 & 0.0 & - & 326 & 53.8 & 4.0 & 0.0 & 0.0 \\
\hline
\end{tabular}

Vuosina 1955 ja 1956 suoritetuissa kokeissa sipuli (Hytti) ei lainkaan kehittänyt kukintovanoja, vaikka yölliset lämpötilaminimit maan pinnassa istutuksen jälkeen pitkän aikaa olivat alhaiset. Sen sijaan vuorokauden maksimi- ja keskilämpötilat olivat etenkin ensimmäisen viikon aikana vuoden 1957 vastaaviin arvoihin verrattuina korkeat (taulukko 2). On siis todennäköistä, että riittävän korkeat päivälämpötilat voivat estää sipulin kukintaa kompensoimalla alhaisten yölämpötilojen vaikutusta.

Sipulin vegetatiiviseen kehittymiseen ei kylmällä keväällä v. 1957 näyttänyt olevan haitallisia vaikutuksia. Avomaalle istutetut idättämättömät sipulit versoivat jokseenkin yhtä nopeasti kuin kasvihuoneeseen istutetut sipulit idätyksen aikana. 


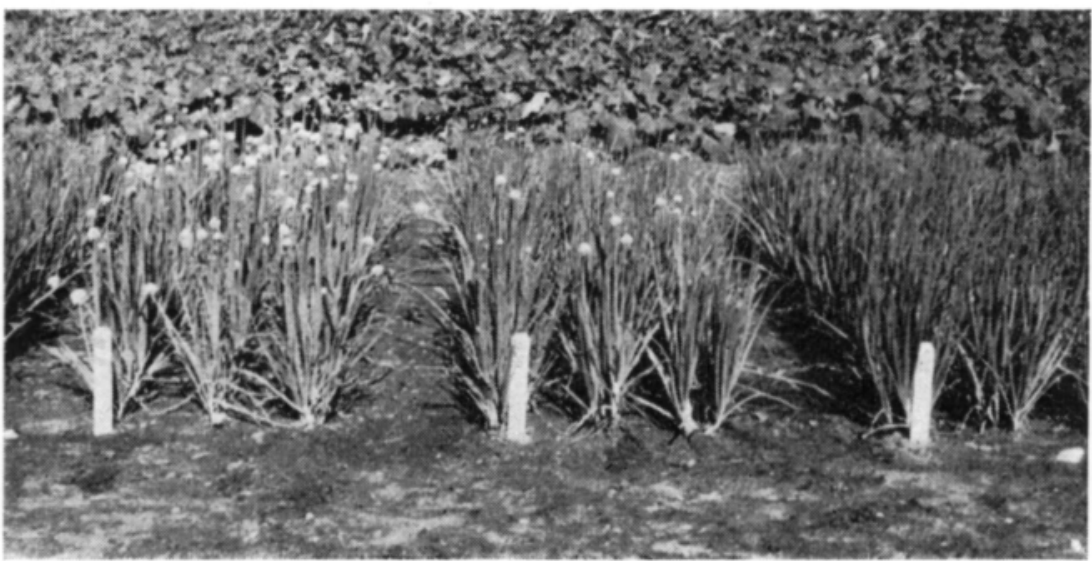

Kuva 1. Sipulin idätyskoe 15. 8. 1957. Vasemmalla idättämätön, keskellä 4 päivää, oikealla 8 päivää idätetty sipuli.

Figure 1. Onion germination experiment 15. 8. 1957.

Left - ungerminated onions. Centre - onions germinated for 4 days. Right - onions germinated for 8 days.

Taulukko 2. Istutuksen jälkeisten yhden ja kahden viikon jaksojen keskimääräiset lämpötilat ja niiden vaikutus ryvässipulin kukkimiseen Tikkurilassa vv. 1955-57. Sipulikanta: Hytti.

Table 2. Average temperatures during one and two sucessive weeks after setting and their effects on the flowering of multiplier onion at Tikkurila during the years 1955-57. Variety of onion: Hytti.

\begin{tabular}{|c|c|c|c|c|c|c|c|}
\hline \multirow{3}{*}{$\begin{array}{l}\text { Vuosi } \\
\text { Year }\end{array}$} & \multicolumn{2}{|c|}{$\begin{array}{l}\text { Minimi maan pinnassa } \\
\text { Minimum at ground level }\end{array}$} & \multicolumn{2}{|c|}{$\begin{array}{c}\text { Maksimi } 2 \mathrm{~m} \text { korkeudella } \\
\text { Maximum at } 2 \mathrm{~m} \text { above } \\
\text { ground level }\end{array}$} & $\begin{array}{l}\text { Keskilän } \\
\text { Average te }\end{array}$ & $\begin{array}{l}\text { impötila } \\
\text { temperature }\end{array}$ & \multirow{2}{*}{$\begin{array}{c}\text { Kukkineita } \\
\text { kasveja } \\
\text { Plants with } \\
\text { flowers }\end{array}$} \\
\hline & $\begin{array}{l}\text { 1. viikon aik. } \\
\text { During 1st } \\
\text { week }\end{array}$ & $\begin{array}{l}\text { 1. ja 2. vii-- } \\
\text { kon aik. } \\
\text { During 1st } \\
\text { and 2nd week }\end{array}$ & $\begin{array}{l}\text { 1. viikon aik. } \\
\text { During 1st } \\
\text { week }\end{array}$ & $\begin{array}{l}\text { 1. ja 2. vii- } \\
\text { kon aik. } \\
\text { During 1st } \\
\text { and 2nd week }\end{array}$ & $\begin{array}{l}\text { 1. viikon aik. } \\
\text { During 1st } \\
\text { week }\end{array}$ & $\begin{array}{l}\text { 1. ja 2. vii- } \\
\text { kon aik. } \\
\text { During 1st } \\
\text { and 2nd week }\end{array}$ & \\
\hline & $\mathrm{C}^{\circ}$ & $\mathrm{C}^{\circ}$ & $\mathrm{C}^{\circ}$ & $\mathrm{C}^{\circ}$ & $\mathrm{C}^{\circ}$ & $\mathrm{C}^{\circ}$ & $\%$ \\
\hline 1955 & $<+1.8$ & $<+1.3$ & 19.0 & 17.9 & 13.0 & 12.0 & 0.0 \\
\hline 1956 & $<-0.8$ & $<+2.2$ & 18.8 & 18.6 & 13.1 & 13.5 & 0.0 \\
\hline 1957 & $>+0.6$ & $>+1.5$ & 11.8 & 13.9 & 7.2 & 8.7 & 95.8 \\
\hline
\end{tabular}

Kukintovanojen vaikutus sipulin satoon oli suuri (taulukko 1). Idättämättömän sipulin sato oli vain runsas kolmasosa idätetyn sipulin sadosta. Idättämättömien kasvien sadosta oli lähes puolet $(49.5 \%$ ) kukintovanojen pilaamaa. Kukintovanoja kehittäneiden sipulien keskipaino oli vain $14.4 \mathrm{~g}$, kun taas normaalit sipulit painoivat keskimäärin $58.9 \mathrm{~g}$. Neljä päivää idätetyn sipulin sato oli — huolimatta 340 kukintovanasta aaria kohti -- lähes yhtä suuri kuin pidemmän aikaa idätettyjen. Kukintovanallisten sipulien osuus sadon painosta oli pieni, vain $1.1 \%$.

Kuten jo aikaisemmin mainittiin, on $\mathrm{t} u \mathrm{l}$ e e $\mathrm{n} \mathrm{t} \mathrm{u} \mathrm{m} \mathrm{i} \mathrm{s} \mathrm{a} \mathrm{j} \mathrm{a} \mathrm{ll}$ a tärkeä merkitys sipulin säilymiseen varastossa. Boswel.. (1) on osoittanut, että myöhään tuleentuneet sipulit versovat varastokauden aikana enemmän kuin aikaisin tuleentuneet. 
Taulukko 3. Idätyksen vaikutus ryvässipulin säilymiseen varastossa varastokautena 1956/57 Tikkurilassa.

Sipulit idätetty ennen istutusta 2 viikkoa kosteassa turvepehkussa n. $20^{\circ} \mathrm{C}$ lämpötilassa. Istutus 25 . 5 ., nosto 14. 9. -56. Kuivatuksen jälkeen sipulit varastoitu kellariin $20-24^{\circ} \mathrm{C}$ lämpötilaan, kumpaakin koejäsentä $204 \mathrm{kpl}$. Sipulikanta: Ylämaa.

Table 3. The effect of germination on the storage of multiplier onion at Tikkurila during the storage period $1956 / 57$.

Before setting the onions were germinated for 2 weeks in a damp bed of moss at approx. $20^{\circ} \mathrm{C}$. Setting took place on 25.5. lifting on 14.9.56. Afterdrying the onions were stored in a cellar at 20 -24. $4^{\circ}$ taking 204 bulbs from each test group. Variety of onion: Ylämaa.

\begin{tabular}{|c|c|c|c|c|c|c|}
\hline \multirow{3}{*}{$\begin{array}{l}\text { Koejäsen } \\
\text { Test group }\end{array}$} & \multicolumn{5}{|c|}{$\begin{array}{l}\text { Varastokauden (1. 10.56-13.5.57) lopussa } \\
\text { At end of storage period }(1.10 .56-13.5 .57)\end{array}$} & \multirow{2}{*}{$\begin{array}{l}\text { Kuivum. } \\
\text { tappio } \\
\text { Dry } \\
\text { loss }\end{array}$} \\
\hline & $\begin{array}{l}\text { Terveitä, verso- } \\
\text { mattomia sipuleita } \\
\text { Healthy, unsprou- } \\
\text { ted onions }\end{array}$ & \multicolumn{2}{|c|}{$\begin{array}{l}\text { Versoneita } \\
\text { sipuleita } \\
\text { Sprouted } \\
\text { onions }\end{array}$} & \multicolumn{2}{|c|}{$\begin{array}{c}\text { Mädäntyneitä } \\
\text { sipuleita } \\
\text { Rotted } \\
\text { onions }\end{array}$} & \\
\hline & $\begin{array}{l}\text { paino- } \% \text { kpl- } \% \\
\% \text { weight } \% \text { no }\end{array}$ & $\begin{array}{l}\text { paino- } \\
\% \text { weig }\end{array}$ & $\begin{array}{l}\mathrm{pl}-\% \\
\text { no }\end{array}$ & $\begin{array}{l}\text { paino- } \\
\% \text { wer }\end{array}$ & $\begin{array}{l}\mathrm{kpl}-\% \\
\% \text { no }\end{array}$ & $\begin{array}{l}\text { paino- } \% \\
\% \text { weight }\end{array}$ \\
\hline \multicolumn{7}{|l|}{ Idättämätön } \\
\hline $\begin{array}{l}\text { Ungerminated } \\
\text { Idätetty }\end{array}$ & 39.2 & $47.7^{*}$ & $52.1^{*}$ & 4.3 & 8.7 & 21.0 \\
\hline Germinated & 54.5 & $16.2^{* *}$ & $17.3^{* *}$ & 7.9 & 10.7 & 21.4 \\
\hline
\end{tabular}

$*=$ versominen pitkälle kehittynyttä. Sprouting far-developed.

** $=$ versominen aivan alussa. Sprouting just commenced.

Kasvitautien tutkimuslaitoksella varastokautena $1956 / 57$ ennen istutusta 2 viikkoa idätetyllä ja idättämättömällä sipulilla suoritetussa säilytyskokeessa ilmeni, että idätetty sipuli versoi varastossa huomattavasti vähemmän kuin idättämätön (taulukko 3). Kasvukauden aikana tehtyjen havaintojen mukaan tuleentuivat idätetyt kasvit lähes kolme viikkoa aikaisemmin kuin idättämättömät. On ilmeistä, että jouduttamalla kasvien tuleentumista idättämällä istukkaita ennen istutusta, voidaan sipulin versomista varastossa vähentää.

\section{Yhteenveto}

Idättämällä istukkaita lämmittämättömässä kasvihuoneessa 4 päivää ennen istutusta, voitiin kevätkylmistä johtuvaa sipulin kukintaa huomattavasti vähentää. Kahdeksan ja kolmentoista päivän idätykset estivät sipulin kukinnan kokonaan.

On todennäköistä, että istutuksen jälkeinen verraten lyhytkin lämmin kausi riittää estämään sipulin kukintaa. Riittävän korkeat päivälämpötilat voivat ehkäistä kukkimista kompensoimalla alhaisten yölämpötilojen vaikutusta.

Idättämättömän sipulin satotulos oli voimakkaan kukinnan (4950 kukintovanaa aarilla) johdosta vain runsas kolmasosa idätetyn sipulin sadosta. Lisäksi 
oli idättämättömien kasvien sadosta lähes puolet kukintovanojen pilaamaa. Neljä päivää idätetyn sipulin sato oli -- huolimatta 340 kukintovanasta aaria kohti lähes yhtä suuri kuin pitemmän aikaa idätettyjen.

Idättämällä istukkaita kahden viikon ajan ennen istutusta, voitiin sipulin versomista varastossa vähentää.

\author{
K I R J A L L I S U U T T A
}

(1) Boswell, V. R. 1923. Influence of the time of maturity of onions on the behavior during storage, and the effect of storage temperature on subsequent vegetative and reproductive development. Proc. of the Amer. Soc. for Hort. Sci. 1923: 234 - 239.

(2) Jamalainen, E. A. 1952. Sipulin tuotantoon vaikuttavista haitallisista tekijöistä ja sipulin viljelyn edistämistoimenpiteistä. (Summary: On factors hampering onion production and on measures for promoting onion cultivation.) Valt. maatal.koetoim. tied. 225: 1-45.

(3) Sørensen, H. 1950. Orienterende dyrkningsforsog med skalotter. Tidskr. for planteavl 53: 307320 .

\title{
S U M M A R Y :
}

THE EFFECTS OF GERMINATION ON THE DEVELOPMENT OF THE INFI,ORESCENCES AND ON THE SPROUTING DURING STORAGE IN MULTIPLIER ONION (Allium cepa L. v. solaninum Alef.)

Kraus Aura

\section{Department of Plant Pathology, Agricultural Research Centre, Tikkurila.}

Cold weather at the beginning of the period of growth often causes the development of the flower stalk in multiplier onion though the sets have been kept in a warm place $\left(\mathbf{1 8}-\mathbf{2 4}{ }^{\circ} \mathrm{C}\right)$ during the previous months of storage (cf. 2). At the beginning of the period of growth in 1957 it was very chilly, resulting in the onion in general flowering plentifully over almost the whole country.

Experiments were made at the Department of Plant Pathology, Agricultural Research Centre, in 1957, to determine whether the flowering of the onions as a result of spring cold could be hindered by allowing the sets to germinate in the spring before setting. The average diameter of the sets was about $4 \mathrm{cms}$. The onions used in the experiment were stored in a temperature of $20-24^{\circ} \mathrm{C}$. Germination took place in an unheated greenhouse, the onions being set in a damp bed of moss for 4, 8 and 13 days. During germination the 24-hourly maximum and minimum temperatures in the greenhouse were on the average $30.0^{\circ} \mathrm{C}$ and $8.9^{\circ} \mathrm{C}$. The mean temperature of the total germination period was about $19^{\circ} \mathrm{C}$.

Cold weather prevailed after setting the onions (on 24. 5). During the first week the 24-hourly minimum temperature at ground level was $0.6^{\circ} \mathrm{C}$ and the maximum $11.8^{\circ} \mathrm{C}$. The mean temperature during this week was $7.2^{\circ} \mathrm{C}$. The following week was also cold. During the period of growth it was ascertained that ungerminated onions developed a great number of flower stalks (almost 5000 stalks per are). In the onions which had germinated for 4 days the number of flower stalks was less, being 340 stalks per are. Germination for 8 and 13 days completely hindered the development of flower stalks (Table 1, Fig. 1). It thus appears that a subsequent comparatively short and warm period after setting is sufficient to hinder the onion from flowering, even if the weather becomes cold later on.

In 1955 and 1956 the onion variety (Hytti) used in the experiments did not flower at all, though the minimum night temperatures at ground level were low after setting. On the other hand, the maxi- 
mum and average 24-hourly temperatures were high compared to the corresponding values in 1957, particularly during the first week (Table 2). Thus it is probable that sufficiently high temperatures during the daytime can prevent the onion from flowering by compensating the effect of low night temperatures.

The presence of a large number of flower stalks had a great effect on the yield of the onion (Table 1). The yield from ungerminated onions was only a third of that from germinated onions. Further, of the yield from the ungerminated plants almost half $(49.5 \%)$ was wasted because of flower stalks. The yield from onions which had germinated for 4 days was almost as big as that from the onions with longer germination periods, in spite of the $\mathbf{3 4 0}$ flower stalks per are.

Boswell (1) has shown that the actual time of maturity is significant with regard to the storage of the onion, so that onions which have maturited at a later date sprout more during storage than those which have maturited earlier. In the storage period $1956-57$ experiments carried out at the Department of Plant Pathology with onions that had been allowed to germinate for two weeks before setting and with ungerminated onions, showed that the germinated onions did not sprout so much while in storage as the ungerminated onions did (Table 3). According to observations made during the period of growth, the germinated plants maturited almost three weeks earlier than the ungerminated plants. 